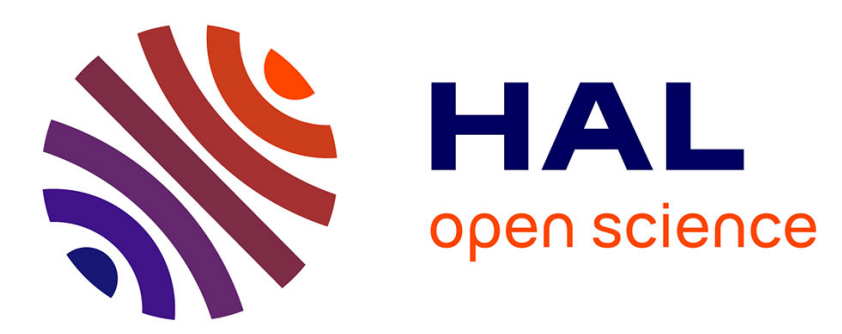

\title{
Towards Stream-based Reasoning and Machine Learning for IoT Applications
}

Markus Endler, Jean-Pierre Briot, Vitor P. Almeida, Francisco Silva E Silva, Edward H Haeusler

\section{- To cite this version:}

Markus Endler, Jean-Pierre Briot, Vitor P. Almeida, Francisco Silva E Silva, Edward H Haeusler. Towards Stream-based Reasoning and Machine Learning for IoT Applications. IEEE Intelligent Systems Conference (IntelliSys'2017), London, U.K, September 2017., Sep 2017, London, United Kingdom. hal-01433729v3

\section{HAL Id: hal-01433729 \\ https://hal.sorbonne-universite.fr/hal-01433729v3}

Submitted on 13 Feb 2018

HAL is a multi-disciplinary open access archive for the deposit and dissemination of scientific research documents, whether they are published or not. The documents may come from teaching and research institutions in France or abroad, or from public or private research centers.
L'archive ouverte pluridisciplinaire HAL, est destinée au dépôt et à la diffusion de documents scientifiques de niveau recherche, publiés ou non, émanant des établissements d'enseignement et de recherche français ou étrangers, des laboratoires publics ou privés. 


\section{Towards Stream-based Reasoning and Machine Learning for IoT Applications - Abstract}

\author{
Markus Endler \\ Dept of Informatics, PUC-Rio \\ Rio de Janeiro, Brazil \\ Email: endler@inf.puc-rio.br
}

\author{
Jean-Pierre Briot \\ LIP6, UPMC-CNRS \& Dept of Informatics, PUC-Rio \\ Paris, France Rio de Janeiro, Brazil \\ Email: Jean-Pierre.Briot@lip6.fr
}

Vitor P. de Almeida

Dept of Informatics, PUC-Rio

Rio de Janeiro, Brazil

Email: valmeida@inf.puc-rio.br
Francisco Silva e Silva

LSDi, Univ. Federal do Maranhão

São Luis, Brazil

Email: fssilva@1sdi.ufma.br
Edward H. Haeusler

Dept of Informatics, PUC-Rio

Rio de Janeiro, Brazil

Email: hermann@inf.puc-rio.br

\begin{abstract}
As distributed IoT applications become larger and more complex, the pure processing of raw sensor and actuation data streams becomes impractical. Instead, data streams must be fused into tangible facts and these pieces of information must be combined with a background knowledge to infer new pieces of knowledge. And since many IoT applications require almost real-time reactivity to stimulus of the environment, such information inference process has to be performed in a continuous, on-line manner. This paper proposes a new semantic model for data stream processing and real-time reasoning based on the concepts of Semantic Stream and Fact Stream, as a natural extension of Complex Event Processing (CEP) and RDF (graph-based knowledge model). The main advantages of our approach are that: (a) it considers time as a key relation between pieces of information; (b) the processing of streams can be implemented using CEP; (c) it is general enough to be applied to any Data Stream Management System (DSMS). Last, we will present challenges and prospects on using machine learning and induction algorithms to learn abstractions and reasoning rules from a continuous data stream.
\end{abstract}

Keywords-Internet of Things (IoT); sensors; data streams; complex event processing (CEP); semantic reasoning; inference; machine learning. 